\title{
当教室における粘膜下口蓋裂28例の検討
}

\author{
藤田 靖・阿部洋子・三浦 英子 \\ 守谷友一・大村武平・林進武
}

\section{Follow-up study on 28 cases of submucous cleft palate}

\author{
Yasushi Fujita - Yoko Abe - Eiko Mrura \\ Tomokazu Moriya - Taketoshi Ohmura - Susumu Hayashi
}

\section{緒言}

粘膜下口蓋裂は，1825年 Roux ${ }^{1)}$ によって初めて報告 され，1910年 Kelly2)によって名付けられたといわれて 扣り，比較的古くから知られていたにもかかわらず，い まだ報告が少なく，その本態や治療法などについても 不明な点が多い, すなわち, 治療法は, 従来より外科的 処置、スピーチ・エイドまたは言語治療が広く適用され ているが，どのような症例に対してどの方法が良いかと なると，まだはっきりとした基準がない．また，外科的 に処置する場合でも，手術時期や術式は術者によって異 なる，たとえば，術式については，単なる口蓋後方移動 術だけで良いのか，それとも咽頭弁移植術を行った方が 良いのか, 論争されている現状である (Porterfield ら², 1976).

そこで，過去10年間にいわゆる粘膜下口蓋裂と診断 し，治療を行った28症例について追跡調查を行い，治療 法と予後との関係を中心に検討した。

\section{対象}

昭和 44 年 4 月より昭和 54 年 3 月末日までの 10 年間に東 北大学崡学部付属病院口腔外科を受診し, 粘膜下口蓋裂 と診断された28名を対象とした。

\section{結果}

\section{1. 頻 度}

昭和 44 年 4 月より昭和 54 年 3 月末日までの 10 年間に東

東北大学㮸学部第 1 口腔外科学教公（主任: 林 進 武教授)

First Department of Oral Surgery, School of Dentistry, Tohoku University (Chief: Prof. Susumu Hayashi)

受付日：昭和55年 5 月 29 日

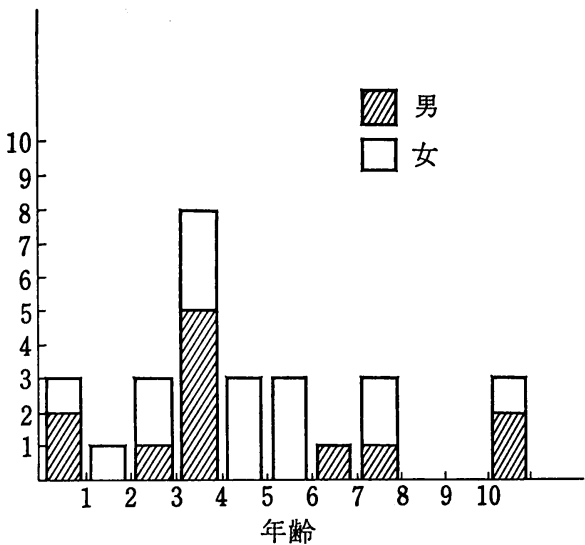

図 1 初診時年龄別症例数

表 1 唇裂口蓋裂の中での粘膜下口蓋裂の頻度

\begin{tabular}{c|c|c|c|c}
\hline & 口 唇 裂 & 唇颚口蓋裂 & 口 蓋 裂 & 総 数 \\
\hline 男 & 84 & $5 / 217$ & $7 / 58$ & $12 / 359$ \\
女 & 77 & $1 / 131$ & $15 / 97$ & $16 / 305$ \\
\hline 総 数 & 161 & $6 / 348$ & $22 / 155$ & $\begin{array}{c}28 / 664 \\
(4.22 \%)\end{array}$ \\
\hline
\end{tabular}

北大学歯学部付属病院口腔外科を受診した唇裂, 口蓋裂 患者は 664 名で, 粘膜下口蓋裂の占める割合は4.22\%で ある(表 1).

2. 性 別

対象とした患者28例の性別は，男12例 (42.85\%), 女 16例 (57.15\%) で, やや女性が多い（表1).

\section{3. 初診時年齢}

対象患者28例の初診時の年齡は 0 歳から19歳まで広い 範囲に及んでいるが，3歳台が 8 例 (28.6\%) で最も多 く, 0 歳台, 2 歳台, 4 歳台, 5 歳台, 7 歳台がそれそ れ 3 例である. 平均は 5 歳 2 か月である（図1）.

\section{4. 主 訴}

言語障害が21例で，全体の75\%を占めている，他に 
は, 口蓋垂の異常が 3 例, 反対咬合，唇裂，唇裂の 2 次 修正およびカリエスの治療希望が备 1 例である（表 2 ）.

\section{5. 口腔内所見}

初診時, Calnan ${ }^{4)}$ (1954) の 3 徵候, すなわち, (1口 蓋垂裂，(2)軟口蓋正中部の筋層の断裂，3硬口蓋後縁正 中部のくさび状欠損のすべてがそろっている典型的な症 例は19例で，他は，硬口蓋後緣正中部のくさび状欠損を 認めない症例が 6 例, 口蓋垂裂を認めない症例が 1 例,

3 改候のらち硬口蓋後縁のくさび状欠損も口蓋垂裂も認 めず，ただ軟口蓋の筋層の断裂しか存在しなかった症例 が 1 例である（表了）。1 例は所見の記截が不十分なた め不明である。

咬合所見は，不明の 4 例をのぞいて，24例中14例に反 対咬合を，1例に過蓋咬合を認めた（表 4 ）。9 例は正

表 2 主訴

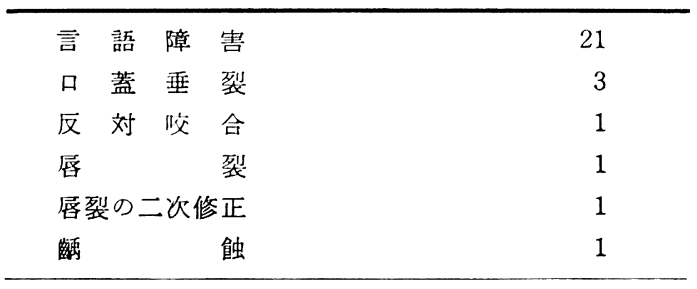

表 3 口蓋所見

\begin{tabular}{|c|c|c|c|c|}
\hline （1）口蓋垂裂 & ／ & 6 & 1 & \multirow{3}{*}{19} \\
\hline （2）筋層の断裂 & 1 & & \multirow[b]{2}{*}{1} & \\
\hline $\begin{array}{l}\text { （3）硬口蓋後縁正中部 } \\
\text { のくさび状欠損 }\end{array}$ & 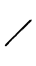 & & & \\
\hline
\end{tabular}

常であった.

\section{6. 初診時の言語機能検査結果}

初診時, 年齡が 2 藏以上で, 言語機能愉査が行えた症 例は24例である。その結果，2 例は正常であったが， 22 例に呼気の舞腔への流出による言語障害を認めた。

呼気の舁腔漏出度 $(\%)$ を $\mathrm{BOC}$ 社製の Wright 式 Respirometer を用いて測定した。 万法は，吹き方が安 定するまで繰り返し練習した後, 努力性最大呼気量を番 開放時と镡閉鎖時にそれぞれ 3 回ずつ测定し，その平均 值を求め，次式によって算出した。

呼気舀腔漏出度 $(\%)$

$$
=\frac{\text { 奥閉鎖時呼気量一系開放時呼気量 }}{\text { 鼻閉鎖時呼気量 }} \times 100
$$

\section{鼻閉鎖洔呼気量}

すでに正常な言語を獲得していた 2 例の呼気奥腔漏出 度はー $1.0 \%, 2.7 \%$, 平均 $0.85 \%$ で，與咽腔の閉鎖機能 は正常と考えられる（表 5 ).

一方，初診時に言語障害を認め，呼気の鼾腔漏出度を 测定した症例は18例であるが，その最高は50.2\%, 最低 でも $3.6 \%$ で，平均 $17.8 \%$ を示し，明らかに呼気が奥腔

表 4 咬合所見

\begin{tabular}{|c|c|c|c|c|c|}
\hline & & & 男 & 女 & 計 \\
\hline 反 & 対 咬 & 合 & 5 & 9 & 14 \\
\hline 過 & 蓋 咬 & 合 & 0 & 1 & 1 \\
\hline 正 & & 常 & 4 & 5 & 9 \\
\hline 不 & & 明 & 3 & 1 & 4 \\
\hline \multicolumn{3}{|c|}{ 計 } & 12 & 16 & 28 \\
\hline
\end{tabular}

表 5 正常言語獲得症例

\begin{tabular}{|c|c|c|c|c|c|c|c|c|}
\hline & $\begin{array}{l}\text { 性別扎よび } \\
\text { 初診時年齢 }\end{array}$ & 主 訴 & 口 蓋所 見 & 咬合 所 胃 & $\begin{array}{c}\text { 初 診 時 } \\
\text { 鼠腔漏出度 } \\
(\%)\end{array}$ & $\begin{array}{l}\text { X-p 所見 } \\
(\mathrm{Vp} / \mathrm{U})\end{array}$ & & 症! \\
\hline 1 & 男14歳10か月 & 口蓋垂 裂 & $\mathrm{M}+\mathrm{U}$ & 反対咬合 & -1.0 & 0.92 & 愿 & 裂 \\
\hline 2 & 男19歳 3 か月 & 唇裂 2 次修正 & $\mathrm{N}+\mathrm{M}+\mathrm{U}$ & 正 常 & 2.7 & 0.76 & 唇 & 裂 \\
\hline
\end{tabular}

$\mathrm{N}$ ：硬口蓋後縁正中部のくさび状欠損

$\mathrm{M}$ : 軟口蓋正中部の觔屋の断裂

$\mathrm{U}$ : 口蓋垂裂

表 6 言語治療のみによる治痛症例

\begin{tabular}{|c|c|c|c|c|c|c|c|}
\hline & $\begin{array}{l}\text { 性別おょび } \\
\text { 初診時年跲 }\end{array}$ & 主 訴 & 口蓋所見 & 咬合所見 & $\begin{array}{c}\text { 初 診 時 } \\
\text { 舅腔漏出度 } \\
(\%)\end{array}$ & $\begin{array}{l}\mathrm{X}-\mathrm{p} \text { 所見 } \\
(\mathrm{Vp} / \mathrm{U})\end{array}$ & 合 併 症 \\
\hline 1 & 男 0 歳 & 口蓋垂裂 & $M+U$ & 正 常 & & 0.78 & 斜 \\
\hline 2 & 女 4 歳 5 か月 & 言語障害 & $\mathrm{N}+\mathrm{M}+\mathrm{U}$ & 反対咬合 & 10.4 & 0.54 & \\
\hline
\end{tabular}

$\mathrm{N}$ ：硬口蓋後縁正中部のくさび状欠損

$\mathrm{M}$ : 軟口蓋正中部の笳層の断裂

$\mathrm{U} ：$ 口蓋垂裂 
表 7 言語治療中の症例

\begin{tabular}{|c|c|c|c|c|c|c|c|}
\hline & $\begin{array}{l}\text { 性別扰よび } \\
\text { 初診時年笭 }\end{array}$ & 主 訴 & 口蓋所見 & 咬合所見 & 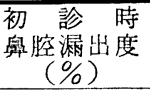 & $\begin{array}{l}\text { X-p 所見 } \\
(\mathrm{Vp} / \mathrm{U})\end{array}$ & 合 併 症 \\
\hline 1 & 男 0 歳 & 唇裂 & $M+U$ & 反対咬合 & & 0.51 & 唇裂 \\
\hline 2 & 女 1 歳 5 か月 & 口 蓋垂裂 & $\mathrm{M}+\mathrm{U}$ & 正 常 & & & \\
\hline 3 & 男 3 歳 3 か月 & 言 語障害 & $\mathrm{N}+\mathrm{M}+\mathrm{U}$ & 反対咬合 & 14.7 & 0.61 & $\begin{array}{l}\tau ん か ん \\
\text { 小眼球症 } \\
\text { 網膜萎縮 }\end{array}$ \\
\hline 4 & 女 3 歳 7 か月 & 言語障害 & $\mathrm{N}+\mathrm{M}+\mathrm{U}$ & 反対咬合 & & 0.64 & \\
\hline 5 & 男 3 歳 8 か月 & 言語障害 & $\mathrm{N}+\mathrm{M}+\mathrm{U}$ & 正 & 11.7 & 0.84 & \\
\hline 6 & 男 7 歳 3 か月 & 言語障害 & $\mathrm{M}+\mathrm{U}$ & 正 & 9.9 & 0.92 & 低 $\mathrm{Ca}$ 血症 \\
\hline
\end{tabular}

$\mathrm{N}$ : 硬口蓋後縁正中部のくさび状欠損

$\mathrm{M}$ : 軟口蓋正中部の筋層の断裂

$\mathrm{U}$ ：口蓋垂裂

表 8 口蓋後方移動術施行症例

\begin{tabular}{|c|c|c|c|c|c|c|c|c|c|}
\hline & $\begin{array}{l}\text { 性別および } \\
\text { 初診時年齢 }\end{array}$ & 主 訴 & 口蓋所見 & 咬合所見 & 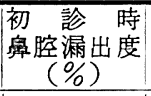 & $\begin{array}{l}\text { X-p 所見 } \\
(\mathrm{Vp} / \mathrm{U})\end{array}$ & 合 併 症 & 手術時年龄 & 結 果 \\
\hline 1 & 女 2 歳 6 か月 & 言語障害 & $\mathrm{N}+\mathrm{M}+\mathrm{U}$ & 反対咬合 & 19.0 & 0.80 & & 3 歳 3 か月 & 俊 良 \\
\hline 2 & 女 3 歳 2 か月 & 反対咬合 & $\mathrm{N}+\mathrm{M}+\mathrm{U}$ & 反対咬合 & 16.3 & 0.37 & & 3 歳 6 か月 & 㯪 良 \\
\hline 3 & 女 2 歳11か月 & 言語障害 & $\mathrm{N}+\mathrm{M}+\mathrm{U}$ & 正 & 16.6 & 0.47 & 血 友 病 & 3 歳 6 か月 & 不 良 \\
\hline 4 & 女 8 か月 & 言語障害 & $\mathrm{N}+\mathrm{M}+\mathrm{U}$ & 正 & & 0.40 & 聴力障害 & 3 歳 7 か月 & 不 良 \\
\hline 5 & 男 2 歳10か月 & 言語障害 & $\mathrm{N}+\mathrm{M}+\mathrm{U}$ & 反対咬合 & 25.5 & 0.71 & & 3 歳 9 か月 & 㯪 良 \\
\hline 6 & 男 3 歳 9 か月 & 言語障害 & $\mathrm{N}+\mathrm{M}+\mathrm{U}$ & 正 & 11.2 & & & 3 歳11か月 & 良 \\
\hline 7 & 女 3 歳 9 か月 & 言語障害 & $\mathrm{N}+\mathrm{M}+\mathrm{U}$ & & & & & 3 歳11か月 & 優 良 \\
\hline 8 & 男 3 憋 8 か月 & 言語障害 & $\mathrm{N}+\mathrm{M}+\mathrm{U}$ & 反対咬合 & & 1.05 & 唇 & 4 歳 1 か月 & 不 良 \\
\hline 9 & 男 6 歳 4 か月 & カリエス & 不 明 & 不 明 & & & 唇裂 & 4 歳 8 か月 & 雾 良 \\
\hline 10 & 女 4 歳10か月 & 言語障害 & M & 正 & 10.7 & 0.99 & & 5 歳 4 か月 & 良 \\
\hline 11 & 女 5 歳 6 か月 & 言語障害 & $\mathrm{N}+\mathrm{M}+\mathrm{U}$ & 反対咬合 & 4.3 & 0.67 & 聴力障害 & 5 歳 8 か月 & 假 良 \\
\hline 12 & 女 5 歳 2 か月 & 言語障害 & $\mathrm{M}+\mathrm{U}$ & 過蓋咬合 & 8.8 & 1. 18 & $\begin{array}{l}\text { 心疾 患 } \\
\text { 裂 }\end{array}$ & 5 歳10か 月 & 晎 良 \\
\hline 13 & 女 7 歳 2 か月 & 言語障害 & $\mathrm{N}+\mathrm{M}+\mathrm{U}$ & 反対咬合 & 3.6 & 0.86 & & 13歳 4 か月 & 良 \\
\hline
\end{tabular}

$\mathrm{N}$ : 硬口蓋後縁正中部のくさび状欠損

$\mathrm{M}$ : 軟口蓋正中部の筋層の断裂

$\mathrm{U}$ : 口蓋垂裂

表 9 咽頭弁移植彷施行症例

\begin{tabular}{|c|c|c|c|c|c|c|c|c|c|}
\hline & $\begin{array}{l}\text { 性別および } \\
\text { 初渗時年柃 }\end{array}$ & 主 訴 & 口蓋所見 & 咬合所見 & \begin{tabular}{|c|}
$\begin{array}{l}\text { 初 喰 } \\
\text { 鼻腔漏出度 } \\
(\%)\end{array}$ \\
\end{tabular} & $\begin{array}{l}\mathrm{X}-\mathrm{p} \text { 所見 } \\
(\mathrm{Vp} / \mathrm{U})\end{array}$ & 合 淤症 & 手術時年龄 & 結 果 \\
\hline 1 & 女 5 歳 3 か月 & 言語障害 & $N+M$ & 正 常 & 50.2 & 0.70 & & 5 歳 8 か月 & 良 \\
\hline 2 & 女 7 歳 7 か月 & 言語障害 & $\mathrm{N}+\mathrm{M}+\mathrm{U}$ & 反対咬合 & 6.3 & & & 8 歳 3 か月 & 優 良 \\
\hline
\end{tabular}

$\mathrm{N}$ : 硬口蓝後縁正中部のくさび状欠損

$M$ : 軟口蓝正中部の笳尿の断裂

$\mathrm{U} ：$ 口蓋垂裂 
表 10 咽頭升を娇用した口蓝後方移動街施行症例

\begin{tabular}{|c|c|c|c|c|c|c|c|c|c|}
\hline & $\begin{array}{l}\text { 性別扰び } \\
\text { 初診時年齢 }\end{array}$ & 主＼cjkstart訴 & 口蓋所見 & 咬合所見 & 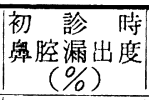 & $\begin{array}{l}\text { X-p 所見 } \\
(\mathrm{Vp} / \mathrm{U})\end{array}$ & 合併症 & 手街時年粭 & 結 果 \\
\hline 1 & 男 3 擟11か月 & 言語障呰 & $\mathrm{N}+\mathrm{M}+\mathrm{U}$ & 不 & 14.6 & & WPW & 4 歳 & 優 良 \\
\hline 2 & 女 4 歳 1 か月 & 言 語障害 & $\mathrm{N}+\mathrm{M}+\mathrm{U}$ & 反対咬合 & 40.1 & 0.86 & & 4 歳 5 か月 & 良 \\
\hline 3 & 男 7 歳 3 か月 & 言語障害 & $\mathrm{N}+\mathrm{M}+\mathrm{U}$ & 反対咬合 & 46.7 & 0.94 & & 14歳 2 か月 & 傮 良 \\
\hline
\end{tabular}

$\mathrm{N}$ ：硬口蓋後縁正中部のくさび状欠損

$\mathrm{M}$ : 㳄口蔡正中部の筋層の断裂

$\mathrm{U}:$ 口蓋垂裂

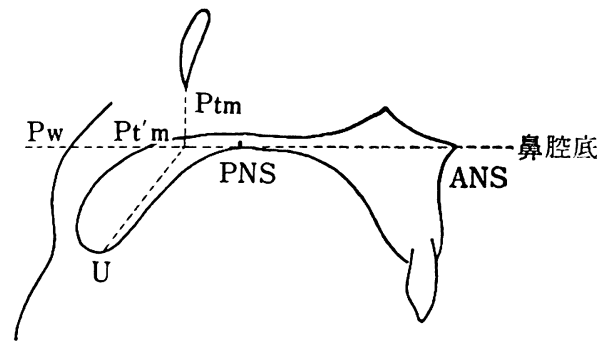

図 2 頭部X線規格写真の計測点扣よび計測 平面

ANS：前鼠梀, PNS：後鼠棘

Ptm：翼口蓋简透過像最下端

$\mathrm{Pt}^{\prime} \mathrm{m}$ : Ptm から鼠腔底に下した垂線の足

$\mathrm{Pw}$ ：風腔底と咽頭後壁との交点

$\mathrm{U}$ ：口蓋垂の尖端

$\mathrm{Pw}-\mathrm{Pt}^{\prime} \mathrm{m}$ ：咽頭腔前後径 ( $\mathrm{Vp}$ )

$\mathrm{Pt}^{\prime} \mathrm{m}-\mathrm{U}$ : 欶口蓋長径 $(\mathrm{U})$

に流出している（表 6〜10）.

\section{7. 頭部 $\mathbf{X}$ 線規格写真の計測結果}

初診時, または治療開始值前に頭部 $\mathbf{X}$ 線規格写真を撮 影した症例は22例である。その咬合位における側貌頭部 X線規格写真を tracing paperに透写し，図2のごとく 計測点および計测平面を設定し，咽頭腔前後径の長さ (Vp) と軟口蓋の長さ（U）との比を求めた。

なんの治療も施さないで正常な言語を獲得した 2 例の 咽頭腔前後径の長さと軟口蓋の長さの比 $(\mathrm{Vp} / \mathrm{U})$ は 0.92 と0.76で, 平均 0.84 である（表 5 ）。 また，言語障 害を認め, 言語治療または外科的処置等治療を必要とし た症例は26例であるが，そのらち治療開始前に咬合位の 側貌頭部X線規格写真を撮影した症例は20例である。そ の咽頭腔前後径の長さと軟口蓋の長さの比 $(\mathrm{Vp} / \mathrm{U})$ は, 最高が1.18，最低が0.37で，平均値は0.742である（表 6〜10). 正常な言語を獲得していた症例よりすかえっ て低い值を示している。

\section{8. 合併症}

28例中11例が表11に示すような種々の疾患を合併して いた，唇裂を合併していた症例は6 例である。
表 11 合 垪症

\begin{tabular}{|c|c|c|}
\hline \multicolumn{2}{|c|}{ 合併症のある患者 } & 11名/28名 \\
\hline & 唇 裂 & 6 \\
\hline $\mathrm{b}$ & 上唇小帯高位付着 & 2 \\
\hline c & 難＼cjkstart聴 & 2 \\
\hline d & てんかん & 2 \\
\hline $\mathrm{e}$ & 小眼球症 & 1 \\
\hline $\mathrm{f}$ & 網膜萎縮 & 1 \\
\hline $\mathrm{g}$ & WPW & 1 \\
\hline h & 斜 頸 & 1 \\
\hline $\mathrm{i}$ & 鼠径ヘルニフ & 1 \\
\hline $\mathrm{j}$ & 先天性低 $\mathrm{Ca}$ 症 & 1 \\
\hline $\mathrm{k}$ & 血友病 & 1 \\
\hline
\end{tabular}

合併症のない患者

17名/28名

\section{9. 治療法とその成綪}

2 例は言語障害を認めなかったが，他の言語障害を認 めた症例は全例言語治療を行い2 例が言語治療のみでほ ぼ正常な発音を獲得した（表 6 ）。言語治療のみでは発 音の改善が期待できないと判断され，手術を施行した症 例は18例で，その術式および症例数は，1）口蓋後方移 動術13例，2）咽頭弁移植術 2 例，3）咽頭弁を併用し た口蓋後方移動術 3 例である（表 8〜10）.

なお，6例は言語治療を行い経過観察中である（表 7 ).

a ) 非手術例

言語治療のみでほぼ正常な発音を猚得した 2 例のら ち，1例は低年㱓のため呼気鼻腔漏出度を測定すること ができなかった．他の 1 例は初診時 $10.4 \%$ の呼気鼻腔漏 出があったにもかかわらず，言語治療開始後 6 か月で 一6.8\%に減少した。 また，咬合位の側貌頭部X線規格 写真における咽頭腔前後径と軟口蓋の長さの比は0.78 と 0.54 で, 平均 0.66 である（表 6 ）.

b ） 口蓋後方移動術施行例

口蓋後方移動術を施行した13例の手術時の年齡は，3 歳台が 7 例, 4 歳台が 2 例, 5 歳台が 3 例, 13歳台が 1 例で, 平均 4 歳 9 か月である(表 8 ). 
表 12 術後の成績からみた術式別手術時年齡

\begin{tabular}{c|c|c|c}
\hline & 口蓋後方移動術 & 咽頭弁移植術 & $\begin{array}{c}\text { 口蓋後方移動衍 } \\
+ \\
\text { 咽頭弁移植術 }\end{array}$ \\
\hline 優 良 & 4.4 & 8.3 & 9.1 \\
良 & 4.5 & 5.8 & 4.5 \\
不良 & 3.7 & - & - \\
\hline 平均 & 4.2 & 7.1 & 7.6 \\
\hline
\end{tabular}

術前に呼気の鼻腔漏出度を测定した 9 症例での漏出度 は, 最高が $25.5 \%$ ，最低が $3.6 \%$ で，平均 $13.73 \%$ であ る。また，咬合位の側貌頭部X線規格写真を撮影したの は10症例で, その咽頭腔前後径と軟口蓋の長さの比は, 最高 1.18 , 最低 0.37 で, 平均値は0.75である（表 8 ）.

術後, 言語治療が終了し,ことばの教室を退級したも のを绶良，Blowing test で鼻腔漏出度が $0 \%$ に近づき， 明らかに発音の改善が認められたものを良, 術前と何ら 変わらなかったるのを不良として判定すると，倀良が 7 例，良が 3 例，不良が 3 例である（表 8 ，図3）。不良 の 3 例の手術年齢は 3 藏 6 か月, 3 歳 7 か月, 4 歳 1 か 月, 平均 3 歳 9 か月で, 一般の口蓋裂手術としては遅い 方であるが，対象とした粘膜下口蓋裂18例の中では比較 的早い時期に手術されている（表 $8 \sim 10 ， 12$ ).

c ) 咽頭弁移植術施行例

呼気鼻腔漏出度が $50.2 \%$ と. $3 \%$ の 2 症例に対して上 茥法による咽頭弁移植術を施行した。手術時の年龄は 5 嘁 8 か月と 8 藏 3 か月で, 比較的高年龄であるにもかか わらず，術後，1例は良，他の 1 例は優良で良い結果を 得ている(表 9, 12, 図 4 ).

d）咽頭弁を併用した口蓋後方移動術施行例

呼気の鼻腔漏出度が $14.6 \%, 40.1 \%, 46.7 \%$ の 3 症例 に対して，4 歳，4歳 5 か月および14藏 2 か月に咽頭弁 を併用してロ蓋後方移動術を施行した（表 10）３例中 2 例, 術前に頭部X線規格写真を撮影したが，それによ ると咽頭腔前後径と軟口蓋の長さの比は0.86と0.94であ る（表 10）。術後の成績は優良が 2 例，良が 1 例で，良 い結果を得ている（表 10，12，図 4 ）.

\section{考察}

Stewart ら 5,6)(1972) が小学生を対象にして， 10,836 人を調へたところ，9人の粘膜下口蓋裂がみつったと いら。これは $1 / 1,200$ の割合となり，比較的高い発生頻 度である。しかし，9人の5ち7人は全く機能障害を認 めず，言語障書を認めたのは 1 人たけで，他の 1 人は高 度の中耳炎であったという。このように，粘膜下口蓋裂 は比較的多いにもかかわらず，そのほとんどが正常な機 能を有するためか，医療機関を訪れる粘膜下口蓋裂患者 は非常に少ない。したがって，唇裂，口蓋裂患者全体の

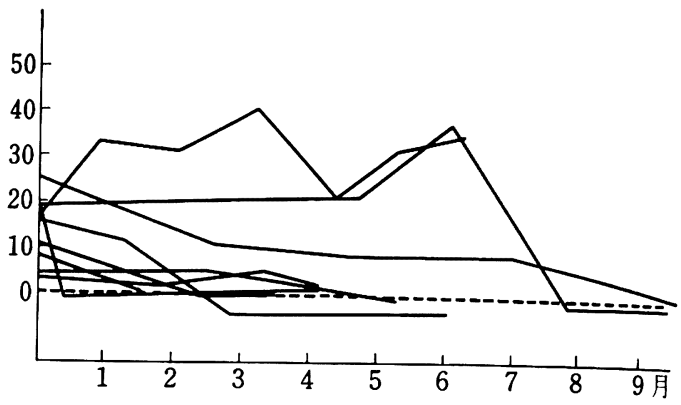

図 3 口蓋後方移動術施行後の系腔漏出度の変化

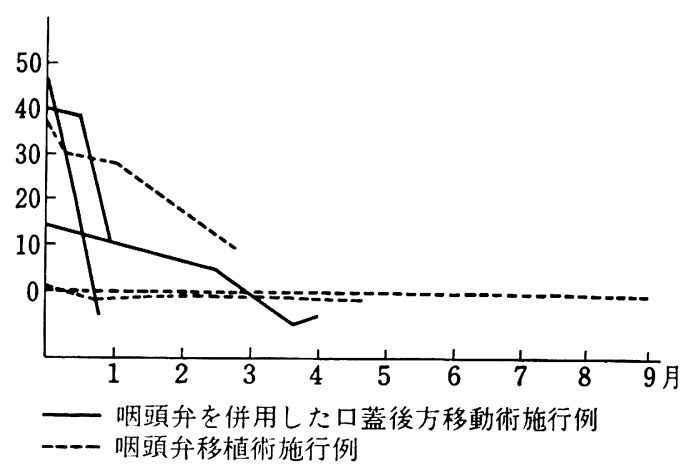

図 4 咽頭弁移植術施行後の鼠腔漏出度の変化

中で占める割合も低く, Gylling $5^{7)}(1965)$ は $5.8 \%$, Porterfield $5^{8)}(1965)$ は.6\%, Crikelair $5^{9)}(1970)$ は $4.3 \%$ にすぎないといっている.われわれの教室でも $4.22 \%$ であり, 諸家の報告と大体一致している。

言語障害は28例中26例に認められたが，その中の21例 が，その言語障害を主訴とし，19例が 2 歳から7歳に来 院している，これは，患児が “ことば”を話すようにな って初めてその異常に気づき，専門家を受診することに よって粘膜下口蓋裂の診断がつけられる場合が非常に多 いことを意味するものと思われる。言語障害を認めた 26 例全例に言語治療を行い，2 例はほほ正常な発音を獲得 したが，18 例はBOC 社製の Wright 式 Respirometer を用いた Blowing test で，明らかに呼気の埤腔への流 出が認められ，いわゆる舆咽腔の閉鎖機能不全があり， 言語治療のみでは発音の改善は期待できないと判断さ れ，手術された。

手術時期について，Gylling ら(1965) はできるた け早い時期をすすめ, Porterfield 58)(1965) は生後 16〜18か月頃に手術すべきたいっている。一方, Weatherley-White · ${ }^{6}$ (1972) はほとんどの粘膜下口蓋 裂患者に言語障害が認められないことから，ただ粘膜下 口蓋裂が存在するからといってすぐに手術することをい ましめ，少なくとも，手術は正確な言語機能検査ができ 
る 4 〜 歳頃まで待つべきだと述べている

Ábyholm $^{10)}$ (1976) は， 7 歳前に手術された場合と後 でされた場合とではその結果が大きく異なるといい，7 藏前に手術することをすすめている。

われわれの症例では, 口蓋後方移動術を行い, 術後, 燠良と判定された 7 症例の手術時の平均年齡は 4.4 歳で あり，また，比較的高い年齡の患者には，症例数は少な いが，咽頭弁を用い良い結果を得ている。したがって， いちがいに一般の口蓋裂のように 2 歳前に手術しなくて も良いよらに考えられる。

術式については, Crikelair ら ${ }^{9}(1970)$ は術前の粘膜 下口蓋裂の程度, 軟口蓋の長さによって術式を選択すれ ば，必ずしもすべての症例において口蓋を後方に移動す る必要はないと述べている。しかし, Porterfield ら3) （1976）は79 例の自験例を調べた結果, 明らかに, 咽頭 弁を用いた症例に良好な結果が得られたことから, 咽頭 弁移植術または咽頭弁を併用した口蓋後方移動術を行う べきたと主張している。

われわれの症例でも, 術前の呼気鼻腔漏出度が高く, しかも，比較的高年龄の患者であったにもかかわらず， 咽頭弁を用いた症例には，術後不良と判定された症例は なかった， 口蓋後方移動術を単独で行った症例の中にの み，不良と判定された症例が 3 例みられた．この中の 1 例は高度の聴力障害を合併しており，いわゆる難聴性の 言語発達遅滞と考えられたが，他の 2 例は術前の頭部 X 線規格写真の計測では，特に著明な Short palate では なく, 呼気鼻腔漏出度も咽頭弁移植術を行った症例より 低かった。しか子手術は他の症例に比へ比較的早い時期 にされている.

Weatherley-White $ら^{6)}(1972)$ は, 粘膜下口蓋裂患者 の鼻咽腔閉鎖機能不全の原因は Short palate たけでは ない, と述べているが, 粘膜下口蓋裂の場合には, 軟口 蓋の長さと鼻咽腔の閉鎖機能とは関係なく, 軟口蓋の筋 の発達程度など他に重要な原因因子があり, したがっ て，単に口蓋を後方に移動するたけでは改善されない場 合があるものと考えられる. Massengill ら¹)(1973)は, 同じ時期に，同じ術式で口蓋を後方に移動した粘膜下口 蓋裂と一般の口蓋裂を比較した結果, 術後の口蓋の長さ はほとんど等しかったにもかかわらず，嶴咽腔の閉鎖機 能は粘膜下口蓋裂の方が悪かったという.

以上のことから, 粘膜下口蓋裂の場合には, Weatherley-White $ら^{6)}(1972)$ がいらように, すぐに外科的 処置にふみきらず，まず，言語治療を行い，正確な言語 機能検査ができる年龄まで待って検查を行い, その結果 によって，手術すべきかとうかを決定した方が良いよう に思われる。術式は鼻腔漏出度の程度にもよるが，咽頭 弁移植術を行った方が良い結果が得られる.
結

論

昭和 44 年 4 月より昭和 54 年 3 月末日までの 10 年間に経 験した粘膜下口蓋裂患者, 男12名, 女16名, 計 28 名の追 跡調査を行い, 次のような結果を得た。

1. 唇裂、口蓋裂の中で占める粘膜下口蓋裂の割合は 4. $22 \%$ であった.

2. 初診時年齢は 0 歳から 19 藏まで広い範国に及んで いるが， 3 藏台が 8 名で最も多く, 28 名中 21 名が 2 歳か ら7歳に来院している.

3. 言語障害は28名中26名に認められたが, 2 名は言語 治療のみでほぼ正常な発音を獲得した。

4. 頭部X線規格写真を計测した結果，軟口蓋の長さ が十分あると考えられた症例でも鼻咽腔閉鎖機能不全が 認められた。

5. BOC 社製の Whight 式 Respirometer を用いて 测定した結果, 明らかに呼気の番腔への流出が認められ た患者に外科的処置を施行した。

6. 術前の呼気番腔漏出度が比較的低い症例に対して 口蓋後方䔟動術を行ったにもかかわらず，その中の 3 例 (23\%) は術後も発音の改善がみられなかった。

7. 咽頭弁移植術を行った症例は, 術前の呼気鼻腔漏 出度が高く, 高年齢であったにもかかわらず, 全例良好 な結果を得た。

本文の主旨は, 第 3 回日本口蓝裂学会総会 (1979年, 京都）で発表した。

\section{引用文 献}

1) Roux, J.P.: Mémoires sur staphylorrhaphie. J.-S. Chaude, Paris, 1825, p 84 . Cited by Dorrance, G.M.: Congenital insufficiency of the palate. Arch Surg 21: 1851930.

2) Kelly, A.B.: Congenital insufficiency of the palate. J Laryng Rhinol Oto 25: 2811910.

3) Porterfield, H.W. and Mohler, L.R.: Submucous cleft palate. Plast Reconstr Surg 58: 60 1976.

4) Calnan, J.: Submucous cleft palate. Brit J Plast Surg 6: 2641954.

5) Stewart, J.M., Ott, J.E. and Lagace, R.. Submucous cleft palate: Prevalence in a school population. Cleft Palate J 9: 2461972.

6) Weatherley-White, R.C.A., Sakura, C.Y., Brenner, L.D., Stewart, J.M. and Ott, J.E.: Submucous cleft palate: Its incidence, natural history, and indications for treatment. Plast Reconstr Surg 49: 2971972.

7) Gylling, U. and Soivio, A.I.: Submucous 
cleft palate: Surgical treatment and results. Acta Chir Scand 129: 2821965.

8) Porterfield, H.W. and Trabue, J.C.: Submucous cleft palate. Plast Reconstr Surg 35: 45 1965.

9) Crikelair, G.F., Striker, P. and Cosman, B.: The surgical treatment of submucous cleft palate. Plast Reconstr Surg 45: 581970.

10) Abyholm, F.E.. Submucous cleft palate. Scand J Plast Reconstr Surg 10: 2091976.

11) Massengill, R., Pickrell, K. and Robinson, M.: Results of pushback operations in treatment of submucous cleft palate. Plast Reconstr Surg 51: 4321973. 